\title{
New Therapeutic Challenges in Autoimmune Diseases
}

\author{
Eun Wha Choi
}

Additional information is available at the end of the chapter

http://dx.doi.org/10.5772/48207

\section{Introduction}

The immune system is the body's main line of defense against invasion by infectious organisms, such as bacteria, virus, and fungi. In normal immune systems, an immune response does not occur against the self-antigen, and is called self-tolerance. Autoimmune diseases occur when body tissues are attacked by the body's own immune system due to loss of tolerance to self-antigens (Dejaco et al., 2006). Under these conditions, body tissues are destroyed by antigen-specific cytotoxic $\mathrm{T}$ cells or auto-antibodies, and the accompanying inflammation can cause functional disability and morbidity. Autoimmune diseases are a heterogenous group of diseases with a wide spectrum of symptoms that affect approximately $6 \%$ of the population (Siatskas et al., 2006). They can be broadly classified as organ-specific or systemic depending on the location of the target antigen and clinical features (Sakaguchi, 2000). Common examples of systemic autoimmune diseases include systemic lupus erythematosus (SLE), rheumatoid arthritis, systemic sclerosis, ankylosing spondylitis, and polymyositis; examples of organ-specific autoimmune diseases include type 1 diabetes, Addison's disease, Hashimoto thyroiditis, Graves' disease, Sjögren's syndrome, vitiligo, pernicious anemia, glomerulonephritis, myasthenia gravis, Goodpasture's syndrome, autoimmune hemolytic anemia, idiopathic thrombocytopenia purpura, and pulmonary fibrosis. The clinical features of autoimmune diseases are very different, but immunemediated mechanisms are associated with the generation of an adaptive immune response toward the target antigen (Kuby, 1994; Siatskas et al., 2006).

Conventional treatments, such as corticosteroids, cyclophosphamide, azathioprine, and methotrexate, are effective in some patients with autoimmune disease, but they are not uniformly effective and are associated with side effects and toxicity (Jantunen et al., 2000; Wiesik-Szewczyk et al., 2010). 
With a better understanding of the pathophysiology of autoimmune diseases, many potential novel therapies focusing on cellular or molecular targets have been developed and evaluated (Nepom, 2002). This chapter provides a review of the pathophysiology and mechanisms underlying the induction of autoimmune diseases and the target sites and mechanisms of new therapies, and may help to understand the concept of new therapeutic trials that enhance or replace conventional therapies by reducing inflammatory immune responses and achieving immunological balance.

\section{Pathophysiology and mechanisms for the induction of autoimmune diseases}

The etiology of autoimmune diseases is unknown; however, autoimmune diseases may be caused by interplays between genetic factors, inappropriate immune regulation, and hormonal and environmental factors. Regarding immune regulation, lymphocytes and antigen-presenting cells play important roles in the generation of an effective immune response. Immune responses can be broadly divided into humoral and cell-mediated immune responses. The term "humoral" is derived from the Latin word "humor," which means body fluid. The humoral immune response involves the interaction of B cells with an antigen and subsequent B-cell proliferation and differentiation into antibody-secreting plasma cells (Kuby, 1994). Apart from mediating the humoral response via antibody production in adaptive immunity, B cells function as antigen-presenting cells and have the ability to activate $\mathrm{T}$ cells. Furthermore, activated B cells may produce pro-inflammatory cytokines, which aggravate local inflammation (Mok MY, 2010). T cells regulate B-cell responses, and inflammatory $\mathrm{T}$ cells infiltrate target tissues, which can lead to tissue damage. Cells expressing major histocompatibility complex (MHC) class II molecules that can present peptides to CD4+ T helper (Th) cells are called antigen-presenting cells. Cells that constitutively express MHC class II molecules, such as B cells, dendritic cells, monocytes, macrophages, thymic dendritic cells, thymic epithelial cells, and human vascular endothelial cells, function as antigen-presenting cells (Kuby, 1994). However, inducible expression of MHC class II molecules can occur in fibroblasts, glial cells, pancreatic beta cells, thyroid epithelial cells, and non-human vascular endothelial cells during an inflammatory response (Kuby, 1994).

In autoimmune disease, immune-mediated mechanisms are associated with the generation of an adaptive immune response against the target self-antigen (Siatskas et al., 2006). Many self-reactive lymphocytes are deleted during development or maturation, but not all selfreactive lymphocytes are eliminated. In normal healthy individuals, the activity of mature, recirculating self-reactive lymphocytes are regulated by clonal anergy or clonal suppression. A breakdown in this regulation results in the activation of self-reactive T- or B-cell clones, inducing humoral or cell-mediated responses against the self-antigen.

As described above, autoimmune diseases do not develop from a single event, but rather from many different events. Many mechanisms have been proposed for the induction of 
autoimmune diseases. Some of the well-known mechanisms include release of sequestered antigens, molecular mimicry, inappropriate expression of MHC class II molecules, cytokine imbalance, dysfunction of idiotype network regulatory pathways, general regulatory T-cell defects, and polyclonal B-cell activation (Kuby, 1994). An overview of the "pathophysiology and mechanisms for the induction of autoimmune disease" is presented in Figure 1.

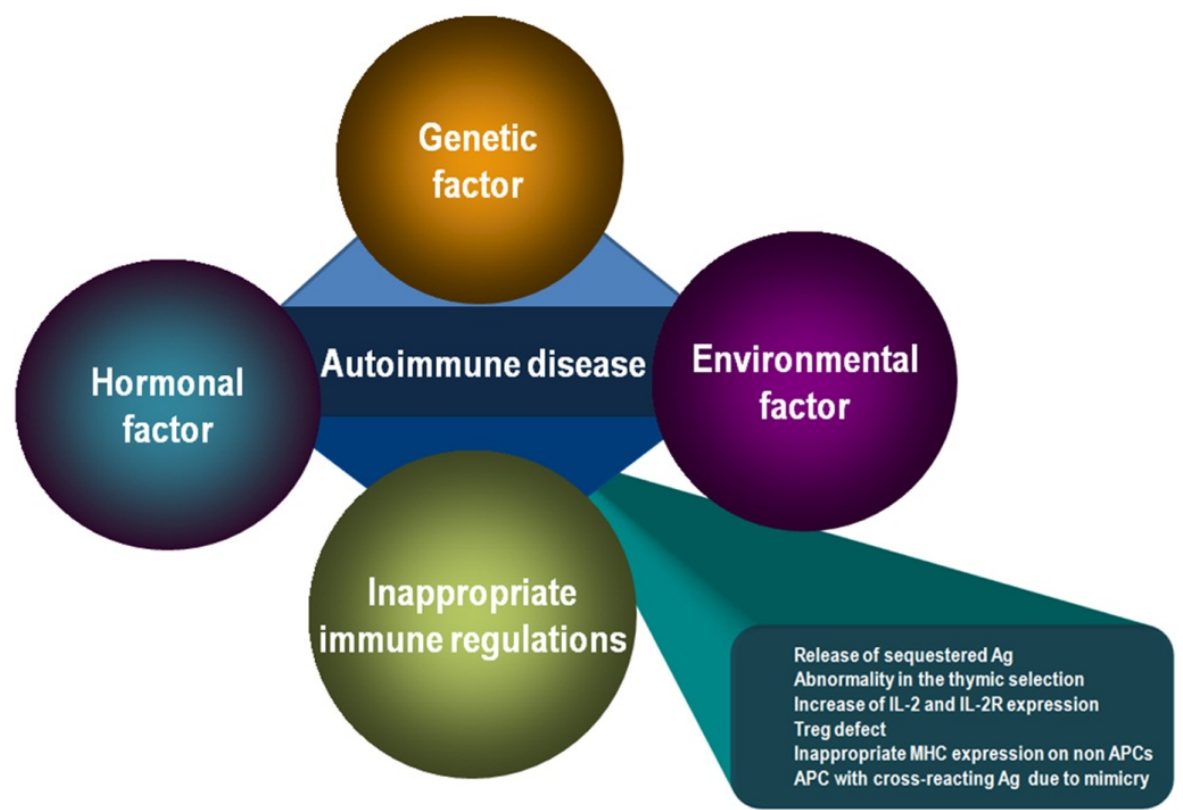

Autoimmune diseases may be caused by interplays between genetic factors, inappropriate immune regulation, and hormonal and environmental factors. Immune-mediated mechanisms underlie the development of autoimmune diseases. (Ag: antigen, IL-2R: IL-2 receptor, Treg: regulatory T cell, MHC: major histocompatibility complex, APC: antigen presenting cell)

Figure 1. Pathophysiology of autoimmune diseases

\subsection{Sequestered antigens}

Induction of tolerance in self-reactive $\mathrm{T}$ cells is thought to occur via exposure of immature lymphocytes to self-antigens during development. Thus, sequestered antigens not seen by the developing immune system will not induce self-tolerance. However, trauma to tissues following an accident or a viral or bacterial infection may release the sequestered selfantigens into circulation, leading to auto-antibody formation on occasion (Kuby, 1994). Multiple sclerosis is the most common autoimmune disorder of the central nervous system (CNS). A study on multiple sclerosis revealed that CD8 $\mathrm{T}$ cells specific for protein sequestered in oligodendrocytes can mount a spontaneous lethal demyelinating attack on the CNS without help from other T- or B-cell subsets or signals from the innate immune system (Na et al., 2008). 


\subsection{Molecular mimicry}

A variety of bacteria and viruses possess antigenic determinants that are identical or similar to host cell components. This molecular mimicry between microbial antigens and host proteins can induce the production of activated $\mathrm{T}$ cells and antibodies that can cross-react with the host's own cells and lead to autoimmune disease. For example, a recent study using bioinformatics tools revealed that some of the identified antigens have been detected in established autoimmune diseases associated with mycobacterial infection (Chodisetti et al., 2012).

\subsection{Inappropriate expression of MHC class II molecules on non-antigen- presenting cells \& MHC molecules and susceptibility to autoimmune diseases}

Inappropriate MHC class II expression was first observed on thyroid cells derived from patients with Graves' disease (Hanafusa et al., 1983) and led to the hypothesis that such expression can lead to the presentation of thyroid autoantigens to $\mathrm{T}$ cells, thereby initiating an autoimmune response. Normally, MHC class II molecules are expressed only on antigenpresenting cells. Healthy beta cells and thyroid acinar cells do not express MHC class II molecules. However, pancreatic beta cells in patients with type I diabetes mellitus (Bosi et al., 1987) and thyroid acinar cells in patients with Grave's disease express high levels of MHC class II (Hanafusa et al., 1983). This inappropriate expression of MHC class II molecules may serve to sensitize Th cells to peptides derived from cells that inappropriately express MHC class II molecules, allowing activation of B cells and cytotoxic T (Tc) cells, or sensitization of $\mathrm{T}_{\mathrm{DTH}}$ cells against self-antigen.

Individuals susceptible to autoimmunity must possess MHC molecules and T-cell receptors capable of binding self-antigens. Expression of certain MHC alleles causes susceptibility to autoimmune diseases, and the presence of certain domains in T-cell receptors has also been linked to many autoimmune diseases (Kuby, 1994). Indeed, several autoimmune diseases, including type I diabetes and rheumatoid arthritis, exhibit a strong association and linkage with specific sequence polymorphisms in MHC class II molecules (Castaño et al., 1990).

Trauma or viral infection in an organ may induce localized inflammation. Increased levels of interferon (IFN)- $\gamma$ can induce the expression of MHC class II molecules on a wide variety of non-antigen-presenting cells, thereby causing autoimmune disease (Todd et al., 1985). Further, the combination of IFN- $\gamma$ with tumor necrosis factor (TNF)- $\alpha$ or interleukin (IL)- $1 \beta$ increases the expression of class I and II antigens in human thyroid follicular cells, compared with the effect of IFN- $\gamma$ alone (Migita et al., 1990).

\subsection{Cytokine imbalance}

CD4+ Th cells can be subdivided into Th1, Th2, Th17, and regulatory T cells, on the basis of the cytokines they produce and the functions they perform (Cooke, 2006). Th1-type cytokines tend to produce the pro-inflammatory responses responsible for killing intracellular parasites such as viruses and certain bacteria, perpetuating autoimmune responses, and causing cell- 
mediated allergies. Preferential activation of Th1 cells plays a central role in the pathogenesis of many autoimmune diseases, including type 1 diabetes mellitus, multiple sclerosis, and rheumatoid arthritis (Emamaullee et al., 2009). The primary cytokines secreted from Th1 cells include IL-2, IFN- $\gamma$, and TNF- $\beta$. Overproduction of these cytokines from activated Th1 cells can induce excessive B-cell activation and autoantibody production (Kuby, 1994). In contrast, induction of Th2 populations results in a dominant protective effect against autoimmunity (Suarez-Pinzon and Rabinovitch, 2001; Sia, 2005). Th2-type cytokines include IL-4, IL-5, and IL-13, which are associated with the promotion of allergic responses, and IL-10, which produces anti-inflammatory responses. In fact, autoimmune diseases can be ameliorated by a reduced Th1 response or a shift toward Th2 responses in some cases, but there are exceptions.

Th17 occurs at the sites of interaction between the internal and external environments of the body. Important cytokines of Th17 include IL-17, IL-12, and IL-23. IL-17 is a potent proinflammatory cytokine that elicits the production of other inflammatory cytokines and chemokines such as TNF- $\alpha$, IL-1ß, IL-6, IL-8, GM-CSF, and MCP-1 by endothelial cells, epithelial cells, and other cell types such as fibroblasts, keratinocytes, synoviocytes, and macrophages (Waite and Skokos, 2012). Thus, IL-17 can amplify ongoing inflammation. IL17 levels were elevated in many inflammatory autoimmune diseases, including systemic sclerosis, psoriasis, and rheumatoid arthritis (Chabaud et al., 1999). Furthermore, several autoimmune conditions that were previously assumed to be mediated by Th1 have now been shown to involve Th17 cells (Cooke, 2006).

\subsection{General regulatory $T$ cell defects}

The CD4+ regulatory T cell subsets include IL-10-producing T regulatory cell type $1(\operatorname{Tr} 1)$, transforming growth factor (TGF)- $\beta$-secreting $\mathrm{T}$ helper cell type 3 (Th3), and a subpopulation of naturally occurring regulatory T cells that express high levels of CD25 and the forkhead box P3 (FoxP3) (Dejaco et al., 2005). Lack of regulatory T cells that express CD4, CD25, and FoxP3 induces severe autoimmunity in both mice and humans (Buckner, 2010). General regulatory T-cell defects cause hyperactivity of both B and T cells. Thus, restoration of regulatory $\mathrm{T}$ cells can reverse autoimmunity. Studies on the functional assays revealed that regulatory $\mathrm{T}$ cells play a crucial role in the modulation of local immune responses (de kleer et al., 2004). Altered generation of regulatory $\mathrm{T}$ cells and insufficient suppression of inflammation are considered pivotal for the initiation and perpetuation of autoimmune diseases because imbalance between pro-inflammatory and regulatory $\mathrm{T}$ cells can lead to the breakdown of self-tolerance (Dejaco et al., 2005). In fact, reduced levels of circulating CD4+CD25high T cells were observed in patients with juvenile idiopathic arthritis (de kleer et al., 2004). Further, lower levels of circulating CD4+CD25high T cells also correlate with higher disease activity or poorer prognosis (de kleer et al., 2004).

\subsection{Dysfunction of the idiotype network regulatory pathways}

Production of anti-idiotype antibodies against self-proteins can contribute to autoimmune disease. For example, in Grave's disease, antibodies produced against the thyroidstimulating hormone (TSH) receptor bind to the receptor and inappropriately stimulate the 
thyroid. Antibodies against the "TSH-specific antibody" (anti-idiotype antibody) can stimulate the TSH receptor. Anti-idiotype antibodies were found in patients with myasthenia gravis (Dwyer et al., 1983) and a patient with Grave's disease (Kuby, 1994).

\subsection{Polyclonal B-cell activation}

Many bacteria and viruses, such as gram-negative bacteria, cytomegalovirus, and EpsteinBarr virus, can induce nonspecific polyclonal B-cell activation without the help of Th cells. Lipopolysaccharide from gram-negative bacteria is sufficient to induce autoimmune disease in an immunologically normal host, suggesting that polyclonal B-cell activation plays a central role in the pathogenesis of systemic autoimmune diseases (Granholm, 1992). Indeed, autoimmune diseases can be arrested by suppressing excessive polyclonal B-cell activation, and autoimmune diseases can be exacerbated by enhancing polyclonal B-cell activation.

\section{Strategies to influence specific immune cells and molecules such as co- stimulatory molecules, cytokines, and chemokines}

The immunity-related strategy for treating autoimmune diseases is to arrest ongoing inflammatory responses, prevent the adaptive memory response, and achieve antigenspecific immunomodulation (Nepom GT, 2002). During the past several decades, strategies using agents that influence cytokines, hyperactivity of B cells, and B cell-T cell interaction have proven to be effective and safe therapies for autoimmune disease (Lacki JK, 2000). Overviews of the "Generation of adaptive immune response against the target self-antigen" and "Target sites of new therapies influencing specific immune cells, molecules, cytokines, and chemokines" are presented in Figure 2.

\subsection{B-cell-based therapy}

Strategies targeting B cells include B-cell depletion therapies, anti-cytokine therapies, B-cell tolerogens, and inhibition of co-stimulatory molecules (Mok MY, 2010).

Potential targets for B-cell therapy include cell surface molecules and co-stimulatory molecules, such as CD20, CD22, B220, MHC class II molecules, CD35 (CR1), CD21 (CR2), CD32 (Fc $\gamma$ RII), CD80 (B7-1), CD86 (B7-2), and CD40.

\subsubsection{B-cell depletion therapies}

CD20 is a B-cell-restricted surface molecule and an activated-glycosylated phosphoprotein that is expressed from pre-B to memory B cells (Mok MY, 2010). Anti-CD20 antibody (Ab) treatment results in B-cell depletion via antibody-dependent cell-mediated cytotoxicity, complement-mediated lysis, and stimulation of apoptosis (Pescovitz, 2006). Anti-CD20 Ab treatment was administered for B-cell depletion in human SLE (Anolik et al., 2007, Smith et al., 2006), autoimmune hemolytic anemia (Quartier et al., 2001; Perrotta et al., 2002), and rheumatoid arthritis (Furst et al., 2007). Clinical trials for SLE proved that anti-CD20 Ab 
treatment has beneficial effects only on B-cell-driven SLE because beneficial effects were seen only in the African American and Hispanic subgroups, which are refractory to standard treatment and are more B-cell dependent (Isenberg et al., 2008). The main complication relating to anti-CD20 Ab treatment is an increased rate of serious infection, which terminated the clinical trials (Hutas et al., 2008).

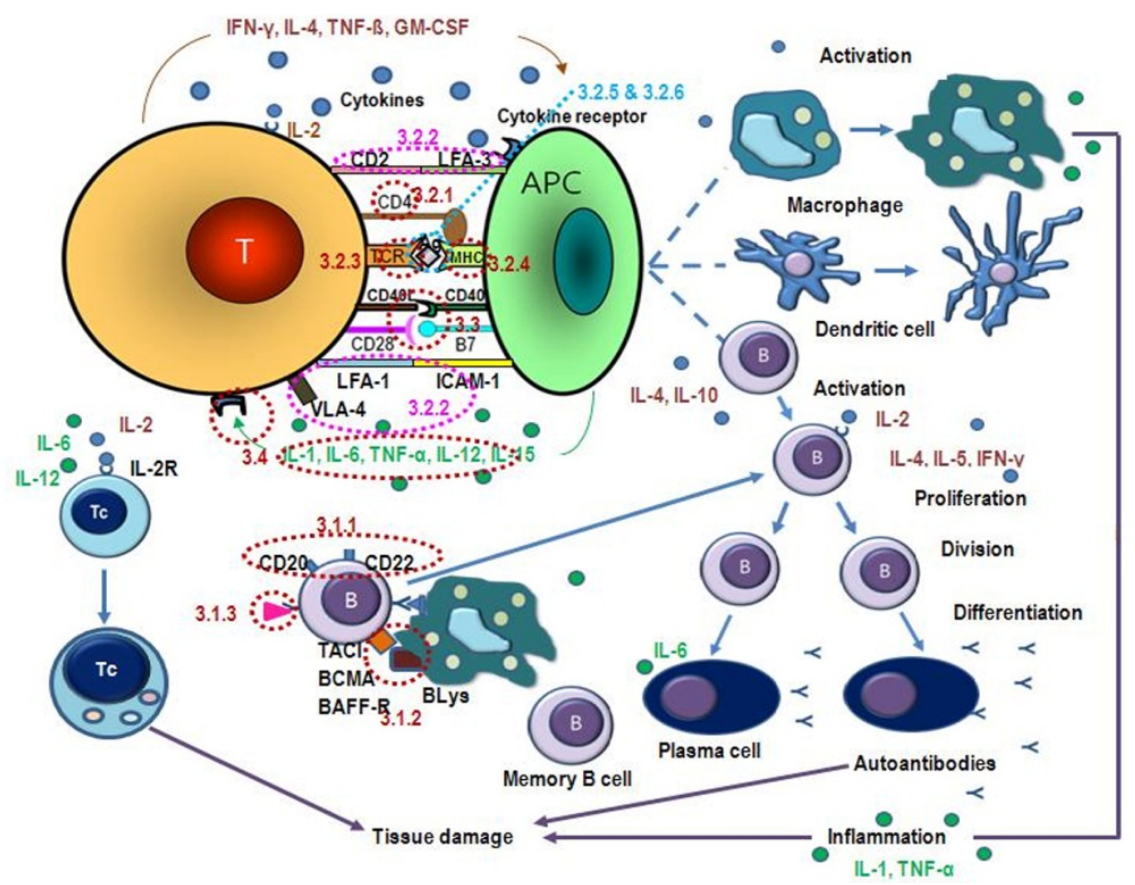

In autoimmune diseases, an adaptive immune response is mounted against the target self-antigen. The target sites of the new therapies are shown.

3.1.1 B-cell depletion therapies

3.1.2 B-cell-related anti-cytokine therapies

3.1.3 Therapy using B-cell tolerogens

3.2.1 Therapies targeting T-cell surface molecules

3.2.2 Therapies targeting T-cell pathways related to trafficking and co-stimulation

3.2.3 T-cell vaccination

3.2.4 Therapies targeting MHC molecules or antigen-presenting cells in the first signal

3.2.5 Therapies targeting antigens in the first signal

3.2.6 Therapy using T-cell tolerogens

3.3 Therapy targeting B cell-T cell interaction (inhibition of co-stimulatory molecules)

3.4 Anti-cytokine therapy (prevention of ongoing inflammatory responses)

(APC: antigen presenting cell, Tc: cytotoxic T cell, TCR: T cell receptor, MHC: major histocompatibility complex, Ag: antigen, LFA: lymphocyte function-associated antigen, CD: cluster of differentiation, VLA: very late antigen, ICAM: intercellular adhesion molecule, TACI: transmembrane activator and calcium modulator and cyclophilin ligand interactor, BCMA: B-cell maturation antigen, BAFF-R: B-cell-activating factor receptor, BLys: B-lymphocyte stimulator, IFN: interferon, IL: interleukin, GM-CSF: granulocyte-macrophage colony-stimulating factor, TNF: tumor necrosis factor)

Figure 2. Target sites of new therapies influencing specific immune cells, molecules, cytokines, and chemokines 
CD22 is a B-cell surface glycoprotein and a specific adhesion molecule that regulates antigen receptor signaling, B-cell activation, and interaction with T cells (Tedder et al., 1997). AntiCD22 Ab treatment was tested in 14 SLE patients in an open-labeled study. No reduction in ANA or anti-dsDNA antibodies (Abs) was observed, but induction of B-cell modulation and evidence of clinical improvement were seen (Dörner et al., 2006; Carnahan et al., 2007). The action of anti-CD22 Abs is achieved by antibody-dependent cell cytotoxicity and induction of signal transduction via downmodulation of B-cell receptor signaling (Carnahan et al., 2007).

\subsubsection{B-cell-related anti-cytokine therapies}

The B-lymphocyte stimulator (BLys), also called B-cell-activating factor (BAFF), is important in B-cell immunity (Moore et al., 1999). BLys is a TNF family ligand expressed on the cells of myeloid origin, such as monocytes, macrophages, and dendritic cells, and can bind to 3 membrane receptors on $\mathrm{B}$ cells, including transmembrane activator and calcium modulator and cyclophilin ligand interactor (TACI), B-cell maturation antigen (BCMA), and BAFF receptor (BAFF-R). Anti-BLys Ab treatment decreased CD20+ B cells, reduced anti-dsDNA Abs and disease flares, and stabilized SLE, in particular, in serologically active SLE patients (Wallace et al., 2009; Wiglesworth et al., 2010).

Treatment with BAFF-R linked to the Fc domain of human IgG1 ameliorated murine SLE, judging from the decrease in anti-dsDNA Abs and proteinuria and the improvement in glomerular lesions (Kayagaki et al., 2002).

TACI-IgG can inhibit BLys and a proliferation-inducing ligand (APRIL), and TACI-IgG treatment decreased proteinuria and prolonged survival in murine lupus (Gross et al., 2000).

\subsubsection{Therapy using B-cell tolerogens}

Abetimus sodium is a synthetic compound of 4 deoxynucleotide sequences bound to a triethylene glycol backbone that can bind to anti-dsDNA Abs and crosslink B-cell receptors that recognize dsDNA. Thus, treatment with abetimus sodium induces deletion or anergy of anti-dsDNA Ab-producing B cells. Abetimus sodium was used as a B-cell tolerogen in SLE patients with lupus nephritis and it exhibited potential efficacy in some SLE patients with elevated anti-dsDNA Abs. However, a phase IV trial was prematurely terminated because of lack of clinical efficacy (Wiesik-Szewczyk et al., 2010).

\subsection{T-cell-based therapy and therapies targeting the first signal}

\subsubsection{Therapies targeting T-cell surface molecules}

Monoclonal antibodies to T-cell surface molecules (CD3, CD4, and CD52) have been effectively used in clinical efficacy trials for autoimmune diseases, but all of them were associated with transient depression of circulating $\mathrm{T}$ cells. For example, treatment of New Zealand black $x$ New Zealand white $(\mathrm{NZB} / \mathrm{W}) \mathrm{F} 1$ and the autoimmune disease-prone non-obese diabetic 
(NOD) mice with anti-CD4 Abs blocked nonspecific overall immune responses (Phillips et al., 2000). A clinical trial using anti-CD52 Abs revealed that profound lymphopenia, with recovery B cells and CD8+ cells and longer lasting CD4 cytopenia can occur (Willis et al., 2001). A monoclonal antibody directed against the $\alpha$ subunit of the high-affinity IL-2 receptor can more specifically block autoreactive Th cells in autoimmunity, because only activated Th cells express the high affinity IL-2R $\alpha$ subunit, CD25. Therapy with a monoclonal antibody to the IL-2 receptor CD25 led to downregulation of the receptor without depleting T cells. Egan et al. (2001) and Haufs and Haneke's (2001) studies showed the efficacy of anti-CD25 Abs in epidermolysis bullosa acquista. In a study on multiple sclerosis, maintenance therapy with anti-CD25 Abs reduced the frequency of CD4+CD25+ regulatory $\mathrm{T}$ cells, but inflammatory activity in multiple sclerosis was substantially reduced with anti-CD25 Ab treatment despite reduction of circulating regulatory $\mathrm{T}$ cells (Oh et al., 2009).

\subsubsection{Therapies targeting T-cell pathways related to trafficking and co-stimulation}

Lymphocyte function-associated antigen-3 (LFA-3, CD58) is a cell-bound immunoglobulin superfamily receptor with only one known ligand, namely, CD2 (Springer et al., 1987). LFA3 is widely expressed on human hematopoietic and non-hematopoietic tissues, leukocytes, erythrocytes, endothelial and epithelial cells, and fibroblasts. The engagement of LFA-3 with CD2 optimizes immune recognition and initiates T-cell expansion and activation. These contact activities can occur between helper $\mathrm{T}$ cells and antigen-presenting cells and cytolytic effectors and target cells. The soluble LFA3/IgG1 fusion protein binds CD2 on T cells and Fc receptor on natural killer cells, macrophages, neutrophils, and mast cells. Thus, the soluble LFA3/IgG1 fusion protein can inhibit immune recognition as well as T-cell expansion and activation.

LFA-1 is found on all T-cells and also on B-cells, macrophages and neutrophils and is involved in recruitment to the site of infection. It binds to ICAM-1 on antigen-presenting cells and functions as an adhesion molecule. Anti-LFA1 Ab treatment elicited an improvement in psoriasis (Papp et al., 2001; Tutrone et al., 2001).

Very late antigen-4 (VLA-4) is an integrin dimer composed of CD49d (alpha) and CD29 (beta). VCAM-1 (integrin receptor) binds to VLA-4 normally expressed on leukocyte plasma membrane, but does not adhere to the appropriate ligands until the leukocytes are activated by chemotactic agents or other stimuli. Treatment with the anti- $\alpha 4$ integrin Abs (VLA-4 Abs), which targets T-cell trafficking pathways, also showed clinical benefit in Crohn's disease and multiple sclerosis (Tubridy et al., 1999; Gordon et al., 2001).

\subsubsection{T-cell vaccination}

Cross-linked $\mathrm{T}$ cells apparently elicit regulatory $\mathrm{T}$ cells specific to $\mathrm{T}$-cell receptor variable region determinants of the autoimmune clones, and it has been shown that a synthetic T-cell receptor variable region peptide can function as a vaccine and an effective therapy (Kuby, 1994). For example, treatment with the IR501 therapeutic vaccine, which consists of a 
combination of 3 peptides derived from $\mathrm{T}$ cell receptors (V $\beta 3, \mathrm{~V} \beta 14$, and V $\beta 17$ ) in Freund's incomplete adjuvant, was safe and well tolerated, and showed clinical improvement in rheumatoid arthritis patients (Moreland et al., 1998).

\subsubsection{Therapies targeting MHC molecules or antigen-presenting cells in the first signal}

Expression of certain MHC alleles causes susceptibility to autoimmune diseases. Thus, selective inhibition of MHC molecules, which are associated with autoimmunity, by using monoclonal antibodies can delay and ameliorate autoimmune diseases (Kuby, 1994). For example, treatment with anti-MHC class II monoclonal Abs (monoclonal Abs to the murine I-E equivalent) prevented thyroidal and pancreatic autoimmunity in BioBreeding/Worcester (BB/W) rats (Boitard et al., 1985). Treatment of anti-I-A monoclonal Abs ameliorated many autoimmune diseases in animal models including lupus nephritis (NZB/W F1) (Adelman et al., 1983), experimental autoimmune uveoretinitis (Rao et al., 1989), and experimental autoimmune myasthenia gravis (Waldor et al., 1983). Engineered antigen-presenting cells have also been used for immunomodulation and tolerance induction. For example, FasLexpressing antigen-presenting cells that specifically interact with Fas molecules on the surface of lymphocytes induce lymphocyte apoptosis (Zhang et al., 1999).

\subsubsection{Therapies targeting antigens in the first signal}

Oral presentation of T-cell-dependent antigens can lead to immunity or tolerance depending on the form of the antigen, dose, and number of feedings (Tomasi, 1980, Titus and Chiller, 1981). Thus, parenteral administration of antigens or antigen analogs was evaluated as immunotherapy for autoimmune diseases. Myelin basic protein (MBP)-specific T cells and symptoms of multiple sclerosis were reduced in myelin-fed, HLA-DR2-negative patients (Weiner et al., 1993). Mice fed MBP do not develop experimental autoimmune encephalomyelitis (experimental allergic encephalomyelitis, EAE) following subsequent injection of MBP (Kuby, 1994). Type II collagen-induced arthritis is an animal model of polyarthritis induced in susceptible mice and rats by immunization with type II collagen, a major component of cartilage. Intragastric administration of soluble type II collagen, prior to immunization with type II collagen in adjuvant, suppressed the incidence of collageninduced arthritis (Nagler-Anderson C, 1986; Trentham et al., 1993).

A synthetic polypeptide comprising a random mixture of alanine, glutamate, lysine, and tyrosine, which can bind MHC and elicit T-cell recognition, acts as an altered antigen ligand. Treatment using this synthetic polypeptide showed beneficial effects on multiple sclerosis (Fusco C, 2001).

\subsubsection{Therapy using T-cell tolerogens}

hCDR1 (TV-4710, Edratide) is a peptide derived from the immunoglobulin Vh region of human anti-dsDNA Abs. Treatment with hCDR1 as a T-cell tolerogen induced regulatory T cells and reduced proteinuria and immune complexes in the kidneys of SLE patients. In this 
study on gene expression in peripheral blood mononuclear cells from SLE patients, treatment using hCDR1 increased in vivo gene expression of TGF- $\beta$, FoxP3 and the anti apoptotic molecule Bcl-xL, but significantly decreased the gene expression of IL- $1 \beta$, TNF- $\alpha$, IFN- $\gamma$, IL-10, BLyS, caspase-3, and caspase-8. hCDR1 treatment also markedly decreased disease activity (Sthoeger et al., 2009).

\subsection{Therapy targeting B cell-T cell interaction (inhibition of co-stimulatory molecules)}

T-cell activation requires 2 signals and cytokines. The first signal is mediated via binding of the T-cell receptor to the antigen presented with MHC molecules on antigen-presenting cells. However, the first signal alone is not sufficient; a second co-stimulatory signal is also required. Thus, co-stimulation is important not only for normal immunity, but also for the pathogenesis of autoimmunity. Therapies targeting the 2 main co-stimulatory pathways B7CD28 and CD40-CD40L have been evaluated. Anti-CD40L Ab treatment reduced inflammation, vasculitis, and fibrosis in the kidney and increased survival in a murine lupus model, the SNF1 mouse (Kalled et al, 1998). Anti-CD40L Ab treatment also elicited clinical improvements such as decrease in anti-dsDNA Abs and hematuria and increase in C3 in some SLE patients. However, thromboembolism complications prevented continuation of the phase II study (Mok et al., 2010). CTLA4Ig is a fusion protein comprising the extracellular domain of CTLA4 and the constant region of immunoglobulin. CTLA4Ig competes with CD28 for binding to B7 thereby inhibiting the B7-CD28 co-stimulatory signal. CTLA4Ig treatment elicited improvements in murine SLE, judging from the decrease in proteinuria and increase in survival (Finck et al., 1994). CTLA4Ig gene therapy also had beneficial effects on canine SLE (Choi et al., 2005) and canine experimental autoimmune thyroiditis (Choi et al., 2008). A phase III clinical trial using CTLA4Ig in human SLE is currently underway (Mok, 2010).

\subsection{Anti-cytokine therapy (prevention of ongoing inflammatory responses)}

Inhibitors of inflammatory cytokines, such as a decoy receptor for inflammatory cytokines, have produced promising results in animal models of autoimmune diseases.

TNF- $\alpha$ is an inflammatory cytokine produced by various cells such as monocytes, macrophages, T cells, and B cells. TNF- $\alpha$ stimulates the production of other cytokines such as IL-1, IL-6, IL-8, and GM-CSF. To prevent ongoing inflammatory responses, TNF-blocking agents were administered in patients with psoriasis, rheumatoid arthritis, or Crohn's disease, and were shown to be efficacious (Chaudhari et al., 2001; Keating and Perry, 2002). However, ANA and anti-dsDNA Abs were observed in some rheumatoid arthritis or Crohn's disease patients treated with TNF-blocking agents (De Bandt et al., 2005; Mohan et al., 2002). TNF-blocking agents were ineffective in multiple sclerosis (Skurkovish et al., 2001). The diseases frequently recurred after discontinuation of TNF-blocking agent therapy. Further, Furst et al. recommend that caution should be exercised when using TNF-blocking agents. According to them, TNF-blocking agents should not be initiated or should be 
discontinued when serious infections occur (Furst et al., 2001). Instances of demyelinatinglike disorders, pancytopenia, and aplastic anemia have been reported in patients receiving TNF blockers (Furst et al., 2002). A recent study reported the association of TNF inhibitor treatment with the risk of elevated liver enzymes, such as ALT and AST in patients with rheumatoid arthritis (Sokolove et al., 2010). A TNF-blocking agent in conjunction with baseline immunosuppressive therapy significantly decreased proteinuria and attenuated arthritis in SLE patients (Aringer et al., 2004). A trial evaluating a TNF-blocking agent in membranous nephritis is currently underway (Wiesik-Szewczyk et al., 2010).

IFN- $\gamma$ is also a pleiotropic cytokine that is a key effector in the pathogenesis of various autoimmune diseases. Intramuscular injections of plasmids with cDNA encoding IFN- $\gamma \mathrm{R} / \mathrm{Fc}$ can retard lupus development and progression in MRL-Fas(lpr) mice. The therapy significantly reduced serum levels of IFN- $\gamma$ and autoantibodies, lymphoid hyperplasia, and glomerulonephritis, and increased survival (Lawson et al., 2000).

IL-12 is an inflammatory cytokine that plays a pivotal role in the development of autoimmune diseases, such as those in the NOD mouse. Gene transfer using a modified form of IL-12 into pancreatic beta islet cells decreased the activity of natural IL-12 and prevented the onset of diabetes in NOD mice (Yasuda et al., 1998).

IL-6 is produced by monocytes, T cells, B cells, and mesangial cells. IL-6 stimulates B-cell maturation and immunoglobulin production. Combined with other cytokines, IL-6 also induces neutrophil activation, T-cell proliferation, and differentiation to cytotoxic $\mathrm{T}$ cells (Tackey et al., 2004). A monoclonal antibody against the IL-6 receptor $\alpha$ chain inhibits the binding of IL-6 to its receptor. Some SLE patients treated with this monoclonal antibody exhibited a significant decrease in acute phase reactant, activated B cells and memory B cells (Lacki et al., 1997). Furthermore, IL-6 receptor Ab treatment has been shown to be rapidly efficacious in patients with severe rheumatoid arthritis (Jones and Ding, 2010). However, complications relating to abnormalities in CBC and serum chemistry, such as neutropenia, increased concentrations of liver enzymes, cholesterol, and triglycerides, were observed in rheumatoid arthritis patients treated with anti-IL-6 receptor $\alpha$ chain monoclonal Abs (Iebba et al., 2012). The US Food and Drug Administration (FDA) approved the intravenous infusion of a monoclonal antibody against the IL- 6 receptor $\alpha$ chain (tocilizumab) in adult patients with severely active rheumatoid arthritis who had an inadequate response to TNF antagonist therapies (http://www.fda.gov/NewsEvents/Newsroom/PressAnnouncements/ucm251572.htm).

An IL-1-blocking agent (IL-1 receptor antagonist) has been approved for use in rheumatoid arthritis. However, its use also increased the incidence of serious bacterial infections. A recent meta-analysis study revealed that the IL-1 receptor antagonist is less effective than TNF- $\alpha$ inhibitors for the treatment of rheumatoid arthritis (Furst et al., 2010).

As described in the previous section, IL-17 plays a central role in early inflammation and eosinophil recruitment. Therapeutic agents that target Th17, such as anti-IL-17 Ab and IL-25, showed promising results in animal models of autoimmunity. Anti-IL-17 Ab treatment reduced Th17 population, and prevented inflammation and bone erosion in experimental 
rheumatoid arthritis by decreasing RANKL and IL-1 (Koenders et al., 2005). Multiple treatments with anti-IL-17 Abs dramatically reduced inflammatory lesions and neurological signs in experimental autoimmune encephalomyelitis (Hofsttter et al., 2005). IL-25 has shown to inhibit Th17 cells and promote the development of Th2 responses (Angkasekwinai et al., 2007). Further, a recent study showed that IL-25 regulates Th17 function in autoimmune inflammation (Kleinschek et al., 2007). Treatment with anti-IL-17 Abs or IL-25 prevented progression to diabetes in pre-diabetic NOD mice, reduced islet inflammation, and prevented glutamic acid decarboxylase (GAD) 65 autoantibody formation (Emamaulle et al., 2009). Clinical trials of anti-IL-17 Abs in autoimmune diseases, including rheumatoid arthritis, psoriasis, and Crohn's disease, are currently underway (www. clinicaltrials.gov). A recent study revealed that a small molecule, halofuginone (HF), selectively inhibits mouse and human Th17 differentiation by activating a cytoprotective signaling pathway, the amino acid starvation response (AAR) (Sundrud et al., 2009). Further, this study showed that HF prevented experimental autoimmune encephalomyelitis by inducing AAR.

\subsection{Protective cytokine gene therapy and induction or replacement of regulatory T cells}

Studies on cytokine gene therapy using viral or nonviral vectors have been conducted in animal models of autoimmune diseases, including type 1 diabetes mellitus, EAE, SLE, colitis, thyroiditis, and various forms of arthritis. The purpose of this therapy is to modify the inappropriate inflammatory immune responses in autoimmune disease. Genes encoding TGF- $\beta$, IL-4, and IL-10 are most frequently protective. For example, IL-10 gene therapy using replication-deficient adenovirus administered directly into the CNS prevented disease progression in murine EAE, whereas systemic administration of IL-10 gene therapy using adenovirus had little effect on EAE (Cua et al., 2001). Intramuscular injection of IL-10 gene therapy prevented diabetes induced by streptozotocin injections in mice (Zhang et al., 2003). IL-4 gene therapy using adenovirus administered directly into limb joints decreased inflammation and improved pathology in a rat model of adjuvant-induced arthritis (Woods et al., 2001). Monthly intramuscular injections of cDNA expression vectors encoding TGF- $\beta 1$ significantly elevated the serum levels of TGF- $\beta$, prolonged survival, and elicited beneficial effects in the MRL/lpr murine model of SLE (Raz et al., 1995). Systemic TGF- $\beta 1$ gene therapy using an adenoviral system followed by syngeneic islet transplantation induced Foxp3+ regulatory cells, restored self-tolerance, and facilitated the survival of islet grafts and recovery of $\beta$-cell function in overtly diabetic NOD mice (Luo et al., 2005). Chen et al. reported that TGF- $\beta$-induced Foxp3 gene expression has the ability to convert CD4+CD25naive $\mathrm{T}$ cells to regulatory $\mathrm{T}$ cells with potent immunosuppressive potential (Chen et al., 2003).

The transfer of CD4+CD25+ regulatory $\mathrm{T}$ cells conferred significant protection against clinical EAE in a mouse model of multiple sclerosis (Kohm et al, 2002). Treatment with in vitro-expanded antigen-specific regulatory $\mathrm{T}$ cells from autoimmune-prone NOD mice also reversed diabetes after disease onset (Tang et al., 2004). Further, antigen-specific T cells transduced with FoxP3 using a retroviral system prevented diabetes in NOD mice (Jaeckel 
et al., 2005). These studies suggested that regulatory $\mathrm{T}$ cells act as main regulators of the immune system and provide a novel approach to cellular immunotherapy for autoimmune diseases.

\section{Stem cell therapy for autoimmune diseases}

\subsection{Hematopoietic stem cell transplantation}

Non-disease prone animals that received bone marrow derived from diseased hosts developed autoimmune diseases (Berisso et al., 1999) and vice versa. This suggested that the hematopoietic compartment plays an important role in autoimmune disease susceptibility, and transplantation of autologous or allogeneic non-autoimmune disease-prone hematopoietic cells can attenuate autoimmune disease. Autologous, syngeneic, and allogeneic bone marrow (or hematopoietic stem cell) transplantations have been performed in animal models of human autoimmune diseases, including EAE (Burt et al., 1998; Karussis et al., 1993), experimental autoimmune myasthenia gravis (Pestronk et al., 1983), adjuvantinduced arthritis (van Bekkum, 1989), collagen-induced arthritis (Kamiya et al., 1993), type 1 diabetes (NOD mice) (Beilhack et al., 2003), and SLE-like autoimmune diseases (MLR/lpr mice and NZB/W F1 mice) (Ikehara, 2001; Smith-Berdan et al., 2007). The results from these animal studies suggested that myelo-ablative therapy supported by stem cell transplantation can result in remission of disease or induction of immune tolerance. The bone marrow was the initial source of hematopoietic stem cells, but peripheral blood is currently used following mobilization procedures comprising a combination of cyclophosphamide and G-CSF (Saccardi and Gualandi, 2008).

The therapeutic concept of hematopoietic stem cell transplantation is to reset the immune system. Thus, patients receive aggressive immunosuppression to eliminate autoreactive lymphocytes (to ablate the immune system), and disease remission occurs via de novo regeneration of immunocytes from hematopoietic stem cells. Two mechanisms have been proposed. The first is re-education of the defective immune system by restoring diverse antigen-specific clones via reactivation of the thymic output and regenerating the adaptive immune system that had became apparently tolerant to self-antigens (Abrahamsson and Muraro, 2008). The second mechanism is reconstitution of the regulatory T-cell pool after stem cell transplantation. Regulatory T cells are important for preventing autoreactivity and control autoimmunity throughout life (Zhang et al., 2009). The rationale of allogeneic stem cell transplantation is substitution of the faulty immune system with a normal healthy one. However, the burden of higher mortality and morbidity due to graft versus host disease prevents its use in autoimmune disease except immune cytopenia. Allogeneic transplantation may be an option for selective patients who are not suitable for or have previously undergone autologous hematopoietic stem cell transplantation.

Autologous BM transplantation for autoimmune diseases has no risk of graft-versus-host disease, but relapses are common (Chan et al., 2008). For example, a case report on autologous hematopoietic stem cell transplantation in non-Hodgkin's lymphoma concurrent 
with Crohn's disease discussed that autologous hematopoietic stem cell transplantation will not provide a long-term cure for Crohn's disease (Anumakonda et al., 2007). In this case report, the authors postulated that autologous hematopoietic stem transplantation led to ablation of activated $\mathrm{T}$ cells for a prolonged period (8 years), but the genetic predisposition (positive family history) concurrent with other environmental factors such as smoking subsequently led to disease relapse. In case of genetically determined autoimmunity, an allogeneic source of stem cells is necessary to prevent a relapse of autoimmunity (Jorgensen et al., 2003). Patients with a refractory autoimmune disease that does not respond to current conventional treatments may be considered for stem cell transplantation. Pilot studies were conducted in systemic sclerosis (Tyndall et al., 1997; Martini et al., 1999), rheumatoid arthritis (Durez et al., 1998), SLE (Burt et al., 1997; Marmont et al., 1997), multiple sclerosis (Burt et al., 1998), and hematological autoimmune diseases, such as idiopathic thrombocytopenia (Lim et al., 1997), autoimmune hemolytic anemia, and Evans syndrome. Some promising results have been reported from phase I/II trial studies, and phase III randomized controlled trials are currently underway (http://clinicaltrials.gov/). Over onethird of patients achieved durable remission and transplant-related mortality reached $12 \%$ in the initial "European group for Blood and Marrow Transplants" (EBMT) registry, which decreased to around 5\% in a recent EBMT study (Farge et al., 2010). Susceptibility to bacterial, viral, and fungal infections increases until the immune system is reconstituted, which makes the hematopoietic stem cell transplantation a high-risk therapy. The major complications of hematopoietic stem cell transplantation include septicemia, pneumonia, increased risk of late infection, infertility, and secondary malignancies, such as acute leukemia and myelodysplastic syndrome.

\subsection{Mesenchymal stem cell transplantation}

Mesenchymal stem cells (MSCs) are multipotent adult stem cells that are the progenitors of multiple mesenchymal lineages (Pittenger et al., 1999). The therapeutic mechanisms of MSC transplantation include capacity for differentiation and transdifferentiation, paracrine effects, immunomodulatory properties, and capacity for directional migration. MSCs have immunoprivileges. MSCs can escape the immune system because they lack MHC class II or co-stimulatory molecules, such as B7, CD40, and CD40L, which leads to poor recognition by $\mathrm{T}$ cells (Deans et al., 2000). Moreover, a number of in vitro studies have revealed that MSCs exert immunosuppressive and immunomodulatory effects on MHC-mismatched lymphocyte proliferation by inhibiting naïve, memory, and activated T cells, B cells, NK cells, and dendritic cells (Bartholomew et al., 2002; Di Nicola et al., 2002). MSCs release paracrine factors, including trophic, chemoattractant, and immunomodulatory factors. Immunomodulatory factors secreted by human MSCs include TGF- $\beta$, HGF, PGE2, hemoxygenase-1, human leukocyte antigen-G5, and IL-10 (Wang et al., 2011). They are constitutively produced by MSCs or after cross-talk with target cells, and their production is also enhanced by cytokines secreted by target cells after cross-talk (Wang et al., 2011). MSCs exhibit immunomodulatory properties by direct cell-to-cell contact and/or release of soluble immunosuppressive factors (Uccelli et al., 2008). MSCs possess the capacity to home to 
mesenchymal tissues, and injured sites in particular, which may also contribute to autoimmune disease treatment. According to the study by Ponte et al., human bone marrow MSCs (BMMSCs) express the following tyrosine kinase receptors: platelet-derived growth factor receptor (PDGF-R) $\alpha$; PDGF-R $\beta$; and insulin-like growth factor receptor (IGF-R). MSCs also express 'regulated upon activation, normal T-cell expressed, and secreted (RANTES) and macrophage-derived chemokine (MDC) receptors (CCR2, CCR3, and CCR4)' and 'stromal-derived factor (SDF)-1 receptor (CXCR4)' (Ponte et al., 2007).

Survival results from an animal study comparing whole bone marrow cell transplantation with adherent cell (MSC)-removed bone marrow cell transplantation revealed that MSCs play a critical role in the treatment of lupus in the MLR/lpr mouse model. All mice treated with whole bone marrow cells survived more than 1 year, but $75 \%$ of mice treated with MSC-removed bone marrow cells died within 3 months (Ishida et al., 1994). Total bone marrow transplants consist of both hematopoietic stem cells and stromal cells, and MSCs play a pivotal role in tolerance induction (Jorgensen et al., 2003).

Initially, MSCs were isolated from the bone marrow and later from various other tissues, including placenta, muscle, cartilage, and fat (da Silva Meirelles L et al., 2006).

Recently, syngeneic, allogeneic, and xenogeneic MSC transplantations have been performed for autoimmune diseases in various animal models, including autoimmune encephalomyelitis (Zappia et al., 2005; Rafei et al., 2009; Constantin et al., 2009), type I diabetes (Fiorina et al., 2009), inflammatory bowel disease (Gonzalez-Rey et al., 2009), rheumatoid arthritis (González et al., 2009), and SLE (Zhou et al., 2008; Sun et al., 2009; Choi et al., 2012). These studies yielded some promising results. For example, long-term serial administration of human adipose tissue-derived MSCs increased survival rates, improved serologic, immunologic, and histologic abnormalities, and decreased the incidence of severe proteinuria in NZB/W F1 mice, a murine SLE model. The levels of IL-4 and IL-10 in the serum and the proportion of CD4+FoxP3+ regulatory $\mathrm{T}$ cells in the spleen were increased in NZB/W F1 mice treated with MSCs, compared to control NZB/W F1 mice treated with saline (Choi et al., 2012). Clinical studies using allogeneic MSC transplantation in refractory SLE patients revealed improvements in serologic parameters and renal function (Sun et al., 2009; Liang J et al., 2010). Furthermore, pilot studies using autologous BMMSC transplantation in patients with refractory Crohn's disease also yielded promising results (Duijvestein et al., 2010; Ciccocioppo $\mathrm{R}$ et al., 2011). Clinical trials using MSCs for diabetes and lupus nephritis are underway (http://clinicaltrials.gov/).

\subsection{Genetically modified stem cell therapy (Stem cell-based gene therapy)}

Gene therapy-assisted stem cell transplantation has become one of the most attractive therapies in clinical immunology (Marmont, 2011). The use of genetically selected or genetically engineered cell types can further control the possibility of disease progression or relapse. Hematopoietic stem cells engineered to express autoantigens in resting antigenpresenting cells can be used to prevent autoimmune diseases. For example, syngeneic transplantation of hematopoietic stem cells encoding proinsulin transgenically targeted to 
antigen-presenting cells completely prevents the development of spontaneous autoimmune diabetes in NOD mice (Steptoe et al., 2003). Transplantation of BM genetically engineered to express myelin oligodendrocyte glycoprotein (MOG) led to the deletion of MOG-specific thymocytes and prevented the induction and progression of EAE (Chan et al., 2008).

Transplantation of genetically engineered autologous BM cells expressing diabetes-resistant MHC class II molecules (I-A ${ }^{b}$ ) into NOD mice prevented the development of autoreactive T cells via negative selection and prevented the progression of diabetes (Tian et al., 2004).

Genetic modification of stem cells or differentiated tissue cells with a decoy receptor for inflammatory cytokines can be used to treat autoimmune diseases. For example, NOD/SCID mice administered with MSCs genetically modified to secrete the soluble TNF receptor II exhibit decreased concentration of serum TNF- $\alpha$.

My previous study revealed that transplantation of adipose tissue-derived MSCs transduced with the CTLA4Ig gene by using a lentiviral vector reduces the inflammatory immune response and improves Th1/Th2 balance in experimental autoimmune thyroiditis (Choi EW et al., 2011). This study showed that MSCs can be efficiently transduced using lentiviral vectors to express therapeutic proteins and can retain their immunophenotype even after genetic manipulation. Moreover, the concentration of murine CTLA4Ig in the culture supernatants of CTLA4Ig-transduced MSCs was sustained at higher passages, indicating that MSCs genetically modified using the lentiviral system provide durable expression of therapeutic genes. Similarly, insertion of inducible regulatory genes into the stem cell compartment is expected to alter disease activity. Genetically modified stem cells that secrete immunomodulatory factors (e.g., IL-10, IDO, PGE2, TGF- $\beta$ ) and home to injured targets have great potential for treating various diseases, including autoimmune diseases.

\section{Conclusion}

During the past several decades, strategies using agents that influence cytokines, hyperactivity of B cells, and B cell-T cell interaction have been developed and some of these agents have proven to be effective and well tolerated therapies for autoimmune diseases. Although some of these treatments have yielded encouraging and promising results, prospective well-planned studies and international cooperation are required to collect experiences and clarify further details on safety and clinical efficacy depending on the disease states and the condition of patients.

Hematopoietic stem cell therapy removes misguided inappropriate immune cells, restores immune cells, and resets or re-educates the immune system. Promising results have been reported from clinical trial studies. Some patients achieved durable remission, and transplantrelated mortality has decreased. MSCs are easily available, possess extensive capacity for in vitro expansion, and exhibit homing effects and immunomodulatory functions. Thus, MSCs have been targeted by researchers as an alternative source of treatment for autoimmune diseases. Stem cell therapy may be integrated with other therapeutic agents, including biologics and new intelligent molecules, for greater immunomodulation. 
Stem cell-based gene therapy has great potential as a novel method for immunomodulation in autoimmune diseases. By identifying the correct gene for autoimmune disease treatment, stem cell-based gene therapy will be able to produce a synergic effect of gene therapy and stem cell therapy. Before they are put to clinical use, genetically engineered cells should be carefully tested at the genetic, molecular, and cellular levels.

Selection and application of the appropriate therapy from among the various new therapeutic agents should be based on the risk-benefit analysis for each patient, because patients with autoimmune diseases exhibit different symptoms and severities and different responses to each treatment. Further studies are warranted to identify new specific targets and determine regimens to optimize the clinical response depending on the disease states. The development of non-toxic and effective novel gene transfer systems and clinical trials to evaluate combination therapies using agents that achieve immunomodulation or induce immune tolerance via different targets are also needed.

\section{Author details}

Eun Wha Choi

Laboratory Animal Research Center, Samsung Biomedical Research Institute, Republic of Korea

School of Medicine, Sungkyunkwan University, Republic of Korea

\section{References}

Abrahamsson S, Muraro PA. Immune re-education following autologous hematopoietic stem cell transplantation. Autoimmunity. 2008;41(8):577-84.

Adelman NE, Watling DL, McDevitt HO. Treatment of (NZB x NZW)F1 disease with anti-IA monoclonal antibodies. J Exp Med. 1983;158(4):1350-5.

Angkasekwinai P, Park H, Wang YH, Wang YH, Chang SH, Corry DB, Liu YJ, Zhu Z, Dong C. Interleukin 25 promotes the initiation of proallergic type 2 responses. J Exp Med. 2007;204(7):1509-17.

Anolik JH, Barnard J, Owen T, Zheng B, Kemshetti S, Looney RJ, Sanz I. Delayed memory B cell recovery in peripheral blood and lymphoid tissue in systemic lupus erythematosus after B cell depletion therapy. Arthritis Rheum. 2007;56(9):3044-56.

Anumakonda V, Hayee B, Chung-Faye G. Remission and relapse of Crohn's disease following autologous haematopoietic stem cell transplantation for non-Hodgkin's lymphoma. Gut. 2007; 56(9): 1325.

Aringer M, Graninger WB, Steiner G, Smolen JS. Safety and efficacy of tumor necrosis factor alpha blockade in systemic lupus erythematosus: an open-label study. Arthritis Rheum. 2004;50(10):3161-9.

Bartholomew A, Sturgeon C, Siatskas M, Ferrer K, McIntosh K, Patil S, Hardy W, Devine S, Ucker D, Deans R, Moseley A, Hoffman R. Mesenchymal stem cells suppress lymphocyte proliferation in vitro and prolong skin graft survival in vivo. Exp Hematol. 2002;30(1):42-8. 
Beilhack GF, Scheffold YC, Weissman IL, Taylor C, Jerabek L, Burge MJ, Masek MA, Shizuru JA. Purified allogeneic hematopoietic stem cell transplantation blocks diabetes pathogenesis in NOD mice. Diabetes. 2003;52(1):59-68.

Berisso GA, van Lint MT, Bacigalupo A, Marmont AM. Adoptive autoimmune hyperthyroidism following allogeneic stem cell transplantation from an HLA-identical sibling with Graves' disease. Bone Marrow Transplant. 1999;23(10):1091-2.

Boitard C, Michie S, Serrurier P, Butcher GW, Larkins AP, McDevitt HO. In vivo prevention of thyroid and pancreatic autoimmunity in the BB rat by antibody to class II major histocompatibility complex gene products. Proc Natl Acad Sci U S A. 1985;82(19):662731.

Bosi E, Todd I, Pujol-Borrell R, Bottazzo GF. Mechanisms of autoimmunity: relevance to the pathogenesis of type I (insulin-dependent) diabetes mellitus. Diabetes Metab Rev. 1987;3(4):893-923.

Buckner JH. Mechanisms of impaired regulation by CD4+CD25+FOXP3+ regulatory T cells in human autoimmune diseases. Nat Rev Immunol. 2010;10:849-59.

Burt RK, Padilla J, Begolka WS, Canto MC, Miller SD. Effect of disease stage on clinical outcome after syngeneic bone marrow transplantation for relapsing experimental autoimmune encephalomyelitis. Blood. 1998 ;91(7):2609-16.

Burt RK, Traynor AE, Cohen B, Karlin KH, Davis FA, Stefoski D, Terry C, Lobeck L, Russell EJ, Goolsby C, Rosen S, Gordon LI, Keever-Taylor C, Brush M, Fishman M, Burns WH. $\mathrm{T}$ cell-depleted autologous hematopoietic stem cell transplantation for multiple sclerosis: report on the first three patients. Bone Marrow Transplant. 1998;21(6):537-41.

Burt RK, Traynor A, Ramsey-Goldman R. Hematopoietic stem-cell transplantation for systemic lupus erythematosus. N Engl J Med. 1997;337(24):1777-8.

Carnahan J, Stein R, Qu Z, Hess K, Cesano A, Hansen HJ, Goldenberg DM. Epratuzumab, a CD22-targeting recombinant humanized antibody with a different mode of action from rituximab. Mol Immunol. 2007;44(6):1331-41.

Castaño L, Eisenbarth GS. Type-I diabetes: a chronic autoimmune disease of human, mouse, and rat. Annu Rev Immunol. 1990;8:647-79.

Chabaud M, Durand JM, Buchs N, Fossiez F, Page G, Frappart L, Miossec P. Human interleukin-17: A T cell-derived proinflammatory cytokine produced by the rheumatoid synovium. Arthritis Rheum. 1999;42(5):963-70.

Chan J, Ban EJ, Chun KH, Wang S, Bäckström BT, Bernard CC, Toh BH, Alderuccio F. Transplantation of bone marrow transduced to express self-antigen establishes deletional tolerance and permanently remits autoimmune disease. J Immunol. 2008;181: 7571-7580.

Chaudhari U, Romano P, Mulcahy LD, Dooley LT, Baker DG, Gottlieb AB. Efficacy and safety of infliximab monotherapy for plaque-type psoriasis: a randomised trial. Lancet. 2001;357(9271):1842-7.

Chen W, Jin W, Hardegen N, Lei KJ, Li L, Marinos N, McGrady G, Wahl SM. Conversion of peripheral CD4+CD25- naive $\mathrm{T}$ cells to $\mathrm{CD} 4+\mathrm{CD} 25+$ regulatory $\mathrm{T}$ cells by TGF-beta induction of transcription factor Foxp3. J Exp Med. 2003;198(12):1875-86. 
Chodisetti SB, Rai PK, Gowthaman U, Pahari S, Agrewala JN. Potential T cell epitopes of Mycobacterium tuberculosis that can instigate molecular mimicry against host: implications in autoimmune pathogenesis. BMC Immunol. 2012;13(1):13. [Epub ahead of print]

Choi EW, Shin IS, Lee HW, Park SY, Park JH, Nam MH, Kim JS, Woo SK, Yoon EJ, Kang SK, Ra JC, Youn HY, Hong SH. Transplantation of CTLA4Ig gene-transduced adipose tissue-derived mesenchymal stem cells reduces inflammatory immune response and improves Th1/Th2 balance in experimental autoimmune thyroiditis. J Gene Med. 2011 Jan;13(1):3-16.

Choi EW, Shin IS, Lee CW, Youn HY. The effect of gene therapy using CTLA4Ig/silicananoparticles on canine experimental autoimmune thyroiditis. J Gene Med. 2008;10(7):795-804.

Choi EW, Shin IS, Park SY, Park JH, Kim JS, Yoon EJ, Kang SK, Ra JC, Hong SH. Reversal of serologic, immunologic, and histologic dysfunction in mice with systemic lupus erythematosus by long-term serial adipose tissue-derived mesenchymal stem cell transplantation. Arthritis Rheum. 2012;64(1):243-53.

Choi EW, Shin IS, Youn HY, Kim DY, Lee H, Chae YJ, Lee CW. Gene therapy using nonviral peptide vector in a canine systemic lupus erythematosus model. Vet Immunol Immunopathol. 2005;103(3-4):223-33.

Ciccocioppo R, Bernardo ME, Sgarella A, Maccario R, Avanzini MA, Ubezio C, Minelli A, Alvisi C, Vanoli A, Calliada F, Dionigi P, Perotti C, Locatelli F, Corazza GR. Autologous bone marrow-derived mesenchymal stromal cells in the treatment of fistulising Crohn's disease. Gut. 201;60(6):788-98.

Constantin G, Marconi S, Rossi B, Angiari S, Calderan L, Anghileri E, Gini B, Bach SD, Martinello M, Bifari F, Galiè M, Turano E, Budui S, Sbarbati A, Krampera M, Bonetti B. Adipose-Derived Mesenchymal Stem Cells Ameliorate Chronic Experimental Autoimmune Encephalomyelitis. Stem Cells. 2009;27(10):2624-35.

Cooke A. Th17 cells in inflammatory conditions. Rev Diabet Stud. 2006;3(2):72-5.

Cua DJ, Hutchins B, LaFace DM, Stohlman SA, Coffman RL. Central nervous system expression of IL-10 inhibits autoimmune encephalomyelitis. J Immunol. 2001;166(1):6028.

da Silva Meirelles L, Chagastelles PC, Nardi NB. Mesenchymal stem cells reside in virtually all post-natal organs and tissues. J Cell Sci. 2006;119(Pt 11):2204-13.

Deans RJ, Moseley AB. Mesenchymal stem cells: biology and potential clinical uses. Exp Hematol. 2000;28(8):875-84.

De Bandt M, Sibilia J, Le Loët X, Prouzeau S, Fautrel B, Marcelli C, Boucquillard E, Siame JL, Mariette $X$ and the Club Rhumatismes et Inflammation. Systemic lupus erythematosus induced by anti-tumour necrosis factor alpha therapy: a French national survey. Arthritis Res Ther. 2005;7(3):R545-51.

de Kleer IM, Wedderburn LR, Taams LS, Patel A, Varsani H, Klein M, de Jager W, Pugayung G, Giannoni F, Rijkers G, Albani S, Kuis W, Prakken B. CD4+CD25bright regulatory $\mathrm{T}$ cells actively regulate inflammation in the joints of patients with the remitting form of juvenile idiopathic arthritis. J Immunol. 2004;172(10):6435-43. 
Dejaco C, Duftner C, Grubeck-Loebenstein B, Schirmer M. Imbalance of regulatory T cells in human autoimmune diseases. Immunology. 2006;117(3):289-300.

Di Nicola M, Carlo-Stella C, Magni M, Milanesi M, Longoni PD, Matteucci P, Grisanti S, Gianni AM. Human bone marrow stromal cells suppress T-lymphocyte proliferation induced by cellular or nonspecific mitogenic stimuli. Blood. 2002;99(10):3838-43.

Dörner T, Kaufmann J, Wegener WA, Teoh N, Goldenberg DM, Burmester GR. Initial clinical trial of epratuzumab (humanized anti-CD22 antibody) for immunotherapy of systemic lupus erythematosus. Arthritis Res Ther. 2006;8(3):R74.

Duijvestein M, Vos AC, Roelofs H, Wildenberg ME, Wendrich BB, Verspaget HW, KooyWinkelaar EM, Koning F, Zwaginga JJ, Fidder HH, Verhaar AP, Fibbe WE, van den Brink GR, Hommes DW. Autologous bone marrow-derived mesenchymal stromal cell treatment for refractory luminal Crohn's disease: results of a phase I study. Gut. 2010;59(12):1662-9.

Durez P, Toungouz M, Schandené L, Lambermont M, Goldman M.

Remission and immune reconstitution after T-cell-depleted stem-cell transplantation for rheumatoid arthritis. Lancet. 1998;352(9131):881.

Dwyer, Donard S.; Bradley, Ronald J.; Urquhart, C. Kendrick; Kearney, John F. Naturally occurring anti-idiotypic antibodies in myasthenia gravis patients Nature. 1983;301 (5901):611-4.

Egan CA, Brown M, White JD, Yancey KB. Treatment of epidermolysis bullosa acquisita with the humanized anti-Tac mAb daclizumab. Clin Immunol. 2001;101(2):146-51.

Emamaullee JA, Davis J, Merani S, Toso C, Elliott JF, Thiesen A, Shapiro AM. Inhibition of Th17 cells regulates autoimmune diabetes in NOD mice. Diabetes. 2009;58(6):1302-11.

Farge D, Labopin M, Tyndall A, Fassas A, Mancardi GL, Van Laar J, Ouyang J, Kozak T, Moore J, Kötter I, Chesnel V, Marmont A, Gratwohl A, Saccardi R. Autologous hematopoietic stem cell transplantation for autoimmune diseases: an observational study on 12 years' experience from the European Group for Blood and Marrow Transplantation Working Party on Autoimmune Diseases. Haematologica. 2010;95(2):284-92.

Finck BK, Linsley PS, Wofsy D. Treatment of murine lupus with CTLA4Ig. Science 1994;265, 1225-7.

Fiorina P, Jurewicz M, Augello A, Vergani A, Dada S, La Rosa S, Selig M, Godwin J, Law K, Placidi C, Smith RN, Capella C, Rodig S, Adra CN, Atkinson M, Sayegh MH, Abdi R. Immunomodulatory function of bone marrow-derived mesenchymal stem cells in experimental autoimmune type 1 diabetes. J Immunol. 2009;183(2):993-1004.

Furst DE, Breedveld FC, Kalden JR, Smolen JS, Antoni CE, Bijlsma JW, Burmester GR, Cronstein B, Keystone EC, Kavanaugh A, Klareskog L. Updated consensus statement on biological agents for the treatment of rheumatoid arthritis and other rheumatic diseases (May 2002). Ann Rheum Dis. 2002 Nov;61 Suppl 2:ii2-7.

Furst DE, Breedveld FC, Kalden JR, Smolen JS, Burmester GR, Sieper J, Emery P, Keystone EC, Schiff MH, Mease P, van Riel PL, Fleischmann R, Weisman MH, Weinblatt ME. Updated consensus statement on biological agents for the treatment of rheumatic diseases, 2007. Ann Rheum Dis. 2007;66 Suppl 3:iii2-22. 
Furst DE, Keystone EC, Breedveld FC, Kalden JR, Smolen JS, Antoni CE, Burmester GR, Crofford LJ, Kavanaugh A. Updated consensus statement on tumour necrosis factor blocking agents for the treatment of rheumatoid arthritis and other rheumatic diseases. Ann Rheum Dis. 2001;60 Suppl 3:iii2-5.

Fusco C, Andreone V, Coppola G, Luongo V, Guerini F, Pace E, Florio C, Pirozzi G, Lanzillo R, Ferrante P, Vivo P, Mini M, Macrì M, Orefice G, Lombardi ML. HLA-DRB1*1501 and response to copolymer-1 therapy in relapsing-remitting multiple sclerosis. Neurology. 2001;57(11):1976-9.

González MA, Gonzalez-Rey E, Rico L, Büscher D, Delgado M. Treatment of experimental arthritis by inducing immune tolerance with human adipose-derived mesenchymal stem cells. Arthritis Rheum. 2009;60(4):1006-1019.

Gonzalez-Rey E, Anderson P, González MA, Rico L, Büscher D, Delgado M. Human adult stem cells derived from adipose tissue protect against experimental colitis and sepsis. Gut. 2009;58(7):929-939.

Gordon FH, Lai CW, Hamilton MI, Allison MC, Srivastava ED, Fouweather MG, Donoghue S, Greenlees C, Subhani J, Amlot PL, Pounder RE. A randomized placebo-controlled trial of a humanized monoclonal antibody to alpha4 integrin in active Crohn's disease. Gastroenterology. 2001;121(2):268-74.

Granholm NA. Autoimmunity, Polyclonal B-Cell Activation and Infection. Lupus. 1992;1(2):63-74.

Gross JA, Johnston J, Mudri S, Enselman R, Dillon SR, Madden K, Xu W, Parrish-Novak J, Foster D, Lofton-Day C, Moore M, Littau A, Grossman A, Haugen H, Foley K, Blumberg H, Harrison K, Kindsvogel W, Clegg CH. TACI and BCMA are receptors for a TNF homologue implicated in B-cell autoimmune disease. Nature. 2000;404(6781):9959.

Hanafusa T, Pujol-Borrell R, Chiovato L, Russell RC, Doniach D, Bottazzo GF. Aberrant expression of HLA-DR antigen on thyrocytes in Graves' disease: relevance for autoimmunity. Lancet. 1983;2(8359):1111-5.

Haufs MG, Haneke E. Epidermolysis bullosa acquisita treated with basiliximab, an interleukin-2 receptor antibody. Acta Derm Venereol. 2001;81(1):72.

Hofstetter HH, Ibrahim SM, Koczan D, Kruse N, Weishaupt A, Toyka KV, Gold R. Therapeutic efficacy of IL-17 neutralization in murine experimental autoimmune encephalomyelitis. Cell Immunol. 2005;237(2):123-30.

Hutas G. Ocrelizumab, a humanized monoclonal antibody against CD20 for inflammatory disorders and B-cell malignancies. Curr Opin Investig Drugs. 2008;9(11):1206-15.

Iebba F, Di Sora F, Tarasi A, Leti W, Montella T, Montella F. Case report: safety and efficacy of tocilizumab in a patient with rheumatoid arthritis and chronic hepatitis C. Case Report Med. 2012;2012:212381. Epub 2012 Feb 16.

Ikehara S. Treatment of autoimmune diseases by hematopoietic stem cell transplantation. Exp Hematol. 2001;29(6):661-9.

Isenberg D, Gordon C, Merrill J, Urowitz M. New therapies in systemic lupus erythematosus - trials, troubles and tribulations.... working towards a solution. Lupus. 2008;17(11):967-70. 
Ishida T, Inaba M, Hisha H, Sugiura K, Adachi Y, Nagata N, Ogawa R, Good RA, Ikehara S. Requirement of donor-derived stromal cells in the bone marrow for successful allogeneic bone marrow transplantation. Complete prevention of recurrence of autoimmune diseases in MRL/MP-Ipr/Ipr mice by transplantation of bone marrow plus bones (stromal cells) from the same donor. J Immunol. 1994;152(6):3119-27.

Jaeckel E, von Boehmer H, Manns MP. Antigen-specific FoxP3-transduced T-cells can control established type 1 diabetes. Diabetes. 2005;54(2):306-10.

Jantunen E, Myllykangas-Luosujärvi R. Stem cell transplantation for treatment of severe autoimmune diseases: current status and future perspectives. Bone Marrow Transplant. 2000;25(4):351-6.

Jones G, Ding C. Tocilizumab: a review of its safety and efficacy in rheumatoid arthritis. Clin Med Insights Arthritis Musculoskelet Disord. 2010;3:81-9.

Jorgensen C, Djouad F, Apparailly F, Noël D. Engineering mesenchymal stem cells for immunotherapy. Gene Ther. 2003;10(10):928-31.

Kalled SL, Cutler AH, Datta SK, Thomas DW.Anti-CD40 ligand antibody treatment of SNF1 mice with established nephritis: preservation of kidney function. J Immunol. 1998;160(5):2158-65.

Kamiya M, Sohen S, Yamane T, Tanaka S. Effective treatment of mice with type II collagen induced arthritis with lethal irradiation and bone marrow transplantation. J Rheumatol. 1993;20(2):225-30.

Karussis DM, Vourka-Karussis U, Lehmann D, Ovadia H, Mizrachi-Koll R, Ben-Nun A, Abramsky O, Slavin S. Prevention and reversal of adoptively transferred, chronic relapsing experimental autoimmune encephalomyelitis with a single high dose cytoreductive treatment followed by syngeneic bone marrow transplantation. J Clin Invest. 1993;92(2):765-72.

Kayagaki N, Yan M, Seshasayee D, Wang H, Lee W, French DM, Grewal IS, Cochran AG, Gordon NC, Yin J, Starovasnik MA, Dixit VM. BAFF/BLyS receptor 3 binds the B cell survival factor BAFF ligand through a discrete surface loop and promotes processing of NF-kappaB2. Immunity. 2002;17(4):515-24.

Keating GM, Perry CM. Infliximab: an updated review of its use in Crohn's disease and rheumatoid arthritis. BioDrugs. 2002;16(2):111-48.

Kleinschek MA, Owyang AM, Joyce-Shaikh B, Langrish CL, Chen Y, Gorman DM, Blumenschein WM, McClanahan T, Brombacher F, Hurst SD, Kastelein RA, Cua DJ. IL25 regulates Th17 function in autoimmune inflammation. J Exp Med. 2007;204(1):161-70.

Koenders MI, Lubberts E, Oppers-Walgreen B, van den Bersselaar L, Helsen MM, Di Padova FE, Boots AM, Gram H, Joosten LA, van den Berg WB. Blocking of interleukin-17 during reactivation of experimental arthritis prevents joint inflammation and bone erosion by decreasing RANKL and interleukin-1. Am J Pathol. 2005;167(1):141-9.

Kohm AP, Carpentier PA, Anger HA, Miller SD. Cutting edge: CD4+CD25+ regulatory T cells suppress antigen-specific autoreactive immune responses and central nervous system inflammation during active experimental autoimmune encephalomyelitis. J Immunol. 2002;169(9):4712-6. 
Kuby J. 1994: Autoimmunity. In: Kuby J (ed), Immunology, $2^{\text {nd }}$ edn, pp. 445-467. WH Freeman and Company, New York.

Lacki JK. Management of the patient with severe refractory rheumatoid arthritis: are the newer treatment options worth considering? BioDrugs. 2000;13(6):425-35.

Lacki JK, Samborski W, Mackiewicz SH. Interleukin-10 and interleukin-6 in lupus erythematosus and rheumatoid arthritis, correlations with acute phase proteins. Clin Rheumatol. 1997;16(3):275-8.

Lawson BR, Prud'homme GJ, Chang Y, Gardner HA, Kuan J, Kono DH, Theofilopoulos AN. Treatment of murine lupus with cDNA encoding IFN-gammaR/Fc. J Clin Invest. 2000;106(2):207-15.

Liang J, Zhang H, Hua B, Wang H, Lu L, Shi S, Hou Y, Zeng X, Gilkeson GS, Sun L. Allogenic mesenchymal stem cells transplantation in refractory systemic lupus erythematosus: a pilot clinical study. Ann Rheum Dis. 2010;69(8):1423-9.

Lim SH, Kell J, al-Sabah A, Bashi W, Bailey-Wood R. Peripheral blood stem-cell transplantation for refractory autoimmune thrombocytopenic purpura. Lancet. 1997;349(9050):475.

Luo X, Yang H, Kim IS, Saint-Hilaire F, Thomas DA, De BP, Ozkaynak E, Muthukumar T, Hancock WW, Crystal RG, Suthanthiran M. Systemic transforming growth factor-beta1 gene therapy induces Foxp3+ regulatory cells, restores self-tolerance, and facilitates regeneration of beta cell function in overtly diabetic nonobese diabetic mice. Transplantation. 2005;79(9):1091-6.

Marmont AM. Hematopoietic stem cell transplantation for severe autoimmune disease: Progress and perspectives. Cellular Therapy and Transplantation. 2011;2(6): 1-8.

Marmont AM, van Lint MT, Gualandi F, Bacigalupo A. Autologous marrow stem cell transplantation for severe systemic lupus erythematosus of long duration. Lupus. 1997;6(6):545-8.

Martini A, Maccario R, Ravelli A, Montagna D, De Benedetti F, Bonetti F, Viola S, Zecca M, Perotti C, Locatelli F. Marked and sustained improvement 2 years after autologous stem cell transplantation in a girl with systemic sclerosis. Rheumatology (Oxford). 1999;38(8):773.

Migita K, Eguchi K, Otsubo T, Kawakami A, Nakao H, Ueki Y, Shimomura C, Kurata A, Fukuda T, Matsunaga M, Ishikawa N, Ito K, Nagataki S. Cytokine regulation of HLA on thyroid epithelial cells. Clin Exp Immunol. 1990;82(3):548-52.

Mohan AK, Edwards ET, Coté TR, Siegel JN, Braun MM. Drug-induced systemic lupus erythematosus and TNF-alpha blockers. Lancet. 2002;360(9333):646.

Mok MY. The immunological basis of B-cell therapy in systemic lupus erythematosus.

Int J Rheum Dis. 2010;13(1):3-11.

Moore PA, Belvedere O, Orr A, Pieri K, LaFleur DW, Feng P, Soppet D, Charters M, Gentz R, Parmelee D, Li Y, Galperina O, Giri J, Roschke V, Nardelli B, Carrell J, Sosnovtseva S, Greenfield W, Ruben SM, Olsen HS, Fikes J, Hilbert DM. BLyS: member of the tumor necrosis factor family and B lymphocyte stimulator. Science. 1999;285(5425):260-3.

Moreland LW, Morgan EE, Adamson TC 3rd, Fronek Z, Calabrese LH, Cash JM, Markenson JA, Matsumoto AK, Bathon J, Matteson EL, Uramoto KM, Weyand CM, Koopman WJ, 
Heck LW, Strand V, Diveley JP, Carlo DJ, Nardo CJ, Richieri SP, Brostoff SW. T cell receptor peptide vaccination in rheumatoid arthritis: a placebo-controlled trial using a combination of Vbeta3, Vbeta14, and Vbeta17 peptides. Arthritis Rheum. 1998;41(11):1919-29.

Na SY, Cao Y, Toben C, Nitschke L, Stadelmann C, Gold R, Schimpl A, Hünig T. Naive CD8 T-cells initiate spontaneous autoimmunity to a sequestered model antigen of the central nervous system. Brain. 2008;131(Pt 9):2353-65.

Nagler-Anderson C, Bober LA, Robinson ME, Siskind GW, Thorbecke GJ. Suppression of type II collagen-induced arthritis by intragastric administration of soluble type II collagen. Proc Natl Acad Sci U S A. 1986;83(19):7443-6.

Nepom GT. Therapy of autoimmune diseases: clinical trials and new biologics. Curr Opin Immunol. 2002;14(6):812-5.

Oh U, Blevins G, Griffith C, Richert N, Maric D, Lee CR, McFarland H, Jacobson S. Regulatory $\mathrm{T}$ cells are reduced during anti-CD25 antibody treatment of multiple sclerosis. Arch Neurol. 2009;66(4):471-9.

Papp K, Bissonnette R, Krueger JG, Carey W, Gratton D, Gulliver WP, Lui H, Lynde CW, Magee A, Minier D, Ouellet JP, Patel P, Shapiro J, Shear NH, Kramer S, Walicke P, Bauer R, Dedrick RL, Kim SS, White M, Garovoy MR. The treatment of moderate to severe psoriasis with a new anti-CD11a monoclonal antibody. J Am Acad Dermatol. 2001;45(5):665-74.

Perrotta S, Locatelli F, La Manna A, Cennamo L, De Stefano P, Nobili B. Anti-CD20 monoclonal antibody (Rituximab) for life-threatening autoimmune haemolytic anaemia in a patient with systemic lupus erythematosus. Br J Haematol. 2002;116(2):465-7.

Pescovitz MD. Rituximab, an anti-cd20 monoclonal antibody: history and mechanism of action. Am J Transplant. 2006;6(5 Pt 1):859-66.

Pestronk A, Drachman DB, Teoh R, Adams RN. Combined short-term immunotherapy for experimental autoimmune myasthenia gravis. Ann Neurol. 1983;14(2):235-41.

Phillips JM, Harach SZ, Parish NM, Fehervari Z, Haskins K, Cooke A. Nondepleting antiCD4 has an immediate action on diabetogenic effector cells, halting their destruction of pancreatic beta cells. J Immunol. 2000;165(4):1949-55.

Pittenger MF, Mackay AM, Beck SC, Jaiswal RK, Douglas R, Mosca JD, Moorman MA, Simonetti DW, Craig S, Marshak DR. Multilineage potential of adult human mesenchymal stem cells. Science. 1999;284(5411):143-7.

Ponte AL, Marais E, Gallay N, Langonné A, Delorme B, Hérault O, Charbord P, Domenech J. The in vitro migration capacity of human bone marrow mesenchymal stem cells: comparison of chemokine and growth factor chemotactic activities. Stem Cells. 2007;25(7):1737-45.

Quartier P, Brethon B, Philippet P, Landman-Parker J, Le Deist F, Fischer A. Treatment of childhood autoimmune haemolytic anaemia with rituximab. Lancet. 2001;358(9292):1511-3.

Rafei M, Campeau PM, Aguilar-Mahecha A, Buchanan M, Williams P, Birman E, Yuan S, Young YK, Boivin MN, Forner K, Basik M, Galipeau J. Mesenchymal stromal cells 
ameliorate experimental autoimmune encephalomyelitis by inhibiting CD4 Th17 T cells in a CC chemokine ligand 2-dependent manner. J Immunol. 2009;182(10):5994-6002.

Rao NA, Atalla L, Linker-Israeli M, Chen FY, George FW 4th, Martin WJ, Steinman L. Suppression of experimental uveitis in rats by anti-I-A antibodies. Invest Ophthalmol Vis Sci. 1989;30(11):2348-55.

Raz E, Dudler J, Lotz M, Baird SM, Berry CC, Eisenberg RA, Carson DA. Modulation of disease activity in murine systemic lupus erythematosus by cytokine gene delivery. Lupus. 1995;4(4):286-92.

Saccardi R, Gualandi F. Hematopoietic stem cell transplantation procedures. Autoimmunity. 2008;41(8):570-6.

Sakaguchi S. Animal models of autoimmunity and their relevance to human diseases. Curr Opin Immunol. 2000;12(6):684-90.

Sia C. Imbalance in Th cell polarization and its relevance in type 1 diabetes mellitus. Rev Diabet Stud. 2005;2(4):182-6.

Siatskas C, Chan J, Field J, Murphy K, Nasa Z, Toh BH, Alderuccio F. Gene therapy strategies towards immune tolerance to treat the autoimmune diseases. Curr Gene Ther. 2006;6(1):45-58.

Skurkovich S, Boiko A, Beliaeva I, Buglak A, Alekseeva T, Smirnova N, Kulakova O, Tchechonin V, Gurova O, Deomina T, Favorova OO, Skurkovic B, Gusev E. Randomized study of antibodies to IFN-gamma and TNF-alpha in secondary progressive multiple sclerosis. Mult Scler. 2001;7(5):277-84.

Smith-Berdan S, Gille D, Weissman IL, Christensen JL. Reversal of autoimmune disease in lupus-prone New Zealand black/New Zealand white mice by nonmyeloablative transplantation of purified allogeneic hematopoietic stem cells. Blood. 2007;110(4):13708.

Smith KG, Jones RB, Burns SM, Jayne DR. Long-term comparison of rituximab treatment for refractory systemic lupus erythematosus and vasculitis: Remission, relapse, and retreatment. Arthritis Rheum. 2006;54(9):2970-82.

Sokolove J, Strand V, Greenberg JD, Curtis JR, Kavanaugh A, Kremer JM, Anofrei A, Reed G, Calabrese L, Hooper M, Baumgartner S, Furst DE. Risk of elevated liver enzymes associated with TNF inhibitor utilisation in patients with rheumatoid arthritis. Ann Rheum Dis. 2010;69(9):1612-7.

Springer TA, Dustin ML, Kishimoto TK, Marlin SD. The Lymphocyte Function Associated LFA-1, CD2, and LFA-3 Molecules: Cell Adhesion Receptors of the Immune System. Ann Rev Immunol. 1987;5:223-252.

Steptoe RJ, Ritchie JM, Harrison LC. Transfer of hematopoietic stem cells encoding autoantigen prevents autoimmune diabetes. J Clin Invest. 2003;111(9):1357-63.

Sthoeger ZM, Sharabi A, Molad Y, Asher I, Zinger H, Dayan M, Mozes E. Treatment of lupus patients with a tolerogenic peptide, hCDR1 (Edratide): immunomodulation of gene expression. J Autoimmun. 2009;33(1):77-82.

Suarez-Pinzon WL, Rabinovitch A. Approaches to type 1 diabetes prevention by intervention in cytokine immunoregulatory circuits. Int J Exp Diabetes Res. 2001;2(1):317. 
Sun L, Akiyama K, Zhang H, Yamaza T, Hou Y, Zhao S, Xu T, Le A, Shi S. Mesenchymal stem cell transplantation reverses multiorgan dysfunction in systemic lupus erythematosus mice and humans. Stem cells. 2009; 27(6):1421-1432.

Sundrud MS, Koralov SB, Feuerer M, Calado DP, Kozhaya AE, Rhule-Smith A, Lefebvre RE, Unutmaz D, Mazitschek R, Waldner H, Whitman M, Keller T, Rao A. Halofuginone inhibits TH17 cell differentiation by activating the amino acid starvation response. Science. 2009;324(5932):1334-8.

Tackey E, Lipsky PE, Illei GG. Rationale for interleukin-6 blockade in systemic lupus erythematosus. Lupus. 2004;13(5):339-43.

Tang Q, Henriksen KJ, Bi M, Finger EB, Szot G, Ye J, Masteller EL, McDevitt H, Bonyhadi M, Bluestone JA. In vitro-expanded antigen-specific regulatory $\mathrm{T}$ cells suppress autoimmune diabetes. J Exp Med. 2004;199(11):1455-65.

Tedder TF, Tuscano J, Sato S, Kehrl JH. CD22, a B lymphocyte-specific adhesion molecule that regulates antigen receptor signaling. Annu Rev Immunol. 1997;15:481-504.

Tian C, Bagley J, Cretin N, Seth N, Wucherpfennig KW, Iacomini J. Prevention of type 1 diabetes by gene therapy. J Clin Invest. 2004;114(7):969-78.

Titus RG, Chiller JM. Orally induced tolerance. Definition at the cellular level. Int Arch Allergy Appl Immunol. 1981;65(3):323-38.

Todd I, Pujol-Borrell R, Hammond LJ, Bottazzo GF, Feldmann M. Interferon-gamma induces HLA-DR expression by thyroid epithelium. Clin Exp Immunol. 1985;61(2):265-73.

Tomasi TB Jr. Oral tolerance. Transplantation. 1980;29(5):353-6.

Trentham DE, Dynesius-Trentham RA, Orav EJ, Combitchi D, Lorenzo C, Sewell KL, Hafler DA, Weiner HL. Effects of oral administration of type II collagen on rheumatoid arthritis. Science. 1993;261(5129):1727-30.

Tubridy N, Behan PO, Capildeo R, Chaudhuri A, Forbes R, Hawkins CP, Hughes RA, Palace J, Sharrack B, Swingler R, Young C, Moseley IF, MacManus DG, Donoghue S, Miller $\mathrm{DH}$. The effect of anti-alpha4 integrin antibody on brain lesion activity in MS. The UK Antegren Study Group. Neurology. 1999;53(3):466-72.

Tutrone WD, Kagen MH, Barbagallo J, Weinberg JM. Biologic therapy for psoriasis: a brief history, II. Cutis. 2001;68(6):367-72.

Tyndall A, Black C, Finke J, Winkler J, Mertlesmann R, Peter HH, Gratwohl A. Treatment of systemic sclerosis with autologous haemopoietic stem cell transplantation. Lancet. 1997;349(9047):254.

Uccelli A, Moretta L, Pistoia V. Mesenchymal stem cells in health and disease.

Nat Rev Immunol. 2008;8(9):726-36.

van Bekkum DW, Bohre EP, Houben PF, Knaan-Shanzer S. Regression of adjuvant-induced arthritis in rats following bone marrow transplantation. Proc Natl Acad Sci U S A. 1989;86(24):10090-4.

Waite JC, Skokos D. Th17 response and inflammatory autoimmune diseases. Int J Inflam. 2012;2012:819467.

Waldor MK, Sriram S, McDevitt HO, Steinman L. In vivo therapy with monoclonal anti-I-A antibody suppresses immune responses to acetylcholine receptor. Proc Natl Acad Sci U S A. 1983;80(9):2713-7. 
Wallace DJ, Stohl W, Furie RA, Lisse JR, McKay JD, Merrill JT, Petri MA, Ginzler EM, Chatham WW, McCune WJ, Fernandez V, Chevrier MR, Zhong ZJ, Freimuth WW. A phase II, randomized, double-blind, placebo-controlled, dose-ranging study of belimumab in patients with active systemic lupus erythematosus. Arthritis Rheum. 2009;61(9):1168-78.

Wang J, Liao L, Tan J. Mesenchymal-stem-cell-based experimental and clinical trials: current status and open questions. Expert Opin Biol Ther. 2011;11(7):893-909.

Weiner HL, Mackin GA, Matsui M, Orav EJ, Khoury SJ, Dawson DM, Hafler DA. Doubleblind pilot trial of oral tolerization with myelin antigens in multiple sclerosis. Science. 1993;259(5099):1321-4.

Wiesik-Szewczyk E, Lacki JK, Feleszko W, Olesinska M. Target therapies in systemic lupus erythematosus: current state of the art. Mini Rev Med Chem. 2010;10(10):956-65.

Wiglesworth AK, Ennis KM, Kockler DR. Belimumab: a BLyS-specific inhibitor for systemic lupus erythematosus. Ann Pharmacother. 2010;44(12):1955-61.

Willis F, Marsh JC, Bevan DH, Killick SB, Lucas G, Griffiths R, Ouwehand W, Hale G, Waldmann H, Gordon-Smith EC. The effect of treatment with Campath- $1 \mathrm{H}$ in patients with autoimmune cytopenias. Br J Haematol. 2001;114(4):891-8.

Woods JM, Katschke KJ, Volin MV, Ruth JH, Woodruff DC, Amin MA, Connors MA, Kurata H, Arai K, Haines GK, Kumar P, Koch AE. IL-4 adenoviral gene therapy reduces inflammation, proinflammatory cytokines, vascularization, and bony destruction in rat adjuvant-induced arthritis. J Immunol. 2001;166(2):1214-22.

Yasuda H, Nagata M, Arisawa K, Yoshida R, Fujihira K, Okamoto N, Moriyama H, Miki M, Saito I, Hamada H, Yokono K, Kasuga M. Local expression of immunoregulatory IL12 p40 gene prolonged syngeneic islet graft survival in diabetic NOD mice. J Clin Invest. 1998;102(10):1807-14.

Zappia E, Casazza S, Pedemonte E, Benvenuto F, Bonanni I, Gerdoni E, Giunti D, Ceravolo A, Cazzanti F, Frassoni F, Mancardi G, Uccelli A. Mesenchymal stem cells ameliorate experimental autoimmune encephalomyelitis inducing T-cell anergy. Blood. 2005;106(5):1755-1761.

Zhang L, Bertucci AM, Ramsey-Goldman R, Burt RK, Datta SK. Regulatory T cell (Treg) subsets return in patients with refractory lupus following stem cell transplantation, and TGF-beta-producing CD8+ Treg cells are associated with immunological remission of lupus. J Immunol. 2009;183(10):6346-58.

Zhang ZL, Shen SX, Lin B, Yu LY, Zhu LH, Wang WP, Luo FH, Guo LH. Intramuscular injection of interleukin-10 plasmid DNA prevented autoimmune diabetes in mice. Acta Pharmacol Sin. 2003;24(8):751-6.

Zhang HG, Su X, Liu D, Liu W, Yang P, Wang Z, Edwards CK, Bluethmann H, Mountz JD, Zhou $\mathrm{T}$. Induction of specific $\mathrm{T}$ cell tolerance by Fas ligand-expressing antigenpresenting cells. J Immunol. 1999;162(3):1423-30.

Zhou K, Zhang H, Jin O, Feng X, Yao G, Hou Y, Sun L. Transplantation of human bone marrow mesenchymal stem cell ameliorates the autoimmune pathogenesis in MRL/lpr mice. Cell Mol Immunol. 2008;5(6):417-24. 